\title{
PERENCANAAN DRAINASE DI KAWASAN PUSAT KOTA PALOPO
}

\author{
Andi Kartini Sari S.T.,M.Eng. \\ Fakultas Teknik, Jurusan Sipil, Universitas Andi Djemma Palopo \\ email: tin_sary@yahoo.com
}

\begin{abstract}
ABSTRAK
Kawasan pusat kota Palopo merupakan kawasan yang dipadati oleh fasilitasfasilitas seperti pusat perbelanjaan, pertokoan, perkantoran, rumah makan, pasar tradisional, hotel, bank dan pemukiman warga. Setiap kali turun hujan menyebabkan Genangan air yang memberikan dampak yang negatif antara lain kerusakan jalan, serta terganggunya aktivitas warga di kawasan tersebut. Untuk menanggulangi masalah genangan yang sering terjadi perlu perencanaan sistem drainase yang baik di kawasan pusat kota. Untuk mengidentifikasi masalah genangan air, Dilakukan analisis hidrologi untuk mendapatkan debit saluran rencana berdasarkan data curah hujan yang telah diperoleh.Dalam perencanaan drainese ini direncanakan pula dimensi saluran drainase dan bangunan pelintas (gorong - gorong). Dari hasil perencanaan sistem drainase, diperoleh hasil untuk dimensi drainase yakni $b=2,4 \mathrm{~m}$ dan $h=1,6 \mathrm{~mW}=0,7 \mathrm{mdan} Q=1,95 \mathrm{~m}^{3} /$ det, dengan bentuk saluran trapesium. Untuk banguna pelintas (gorong - gorong) diperoleh hasil untuk dimensi gorong - gorong yakni

$b=1,7 m$ dan $h=2,3 m W=0,9 m$ dan $Q=8,1 \mathrm{~m}^{3} /$ det, dengan bentuk gorong gorong segiempat.

Kata kunci : analisis hidrologi, debit rencana, drainase.
\end{abstract}

\section{PENDAHULUAN}

Seiring dengan pertumbuhan penduduk perkotaan yang amat pesat di Indonesia Khususnya Kota Palopo, pada umumnya melampaui kemampuan penyediaan prasarana dan sarana perkotaan diantaranya permasalahan drainase perkotaan. Akibatnya Permasalahan banjir / genangan semakin meningkat pula. Pada umumnya penanganan sistem drainase di banyak kota di Indonesia masih 
bersifat parsial, sehingga tidak menyelesaikan permasalahan banjir dan genangan secara tuntas .

Air hujan yang jatuh dapat menimbulkan permasalahan tersendiri bagi lingkungan. Dalam kondisi air normal air hujan ketika jatuh ke tanah sebagian besar masuk ke dalam tanah, sebagian lainnya dialirkan, dan sebagian lainnya menguap. Air hujan menjadi permasalahan ketika air tersebut tidak masuk ke dalam tanah (infiltrasi), tidak dialirkan dan menyebabkan timbulnya genangan atau biasa diterjemahkan secara bebas sebagai banjir. Banjir umumnya disebabkan curah hujan yang tinggi disertai dengan tidak memadainya kapasitas sistem drainase. Hampir semua sistem prinsip pada paradigma lama, yakni suatu model drainase mendesain agar aliran runoff secepat mungkin dibuang ke sungai. Ironisnya, prinsip ini pun tidak didukung dimensi bangunan yang cukup. Salah satu daerah yang mengalami permasalahan tersebut adalah Kota Palopo. Daerah ini merupakan salah satu wilayah yang rentan dalam permasalahan ini, karena belum memiliki sistem drainase yang memadai. Dengan intensitas hujan yang cukup tinggi, potensi banjir/genangan sangatlah mungkin terjadi.Konsep perencanaan drainase dengan mempertimbangkan faktor-faktor hidrologi dan fenomena fisik daerah, diharapkan dapat membantu dalam memecahkan permasalahan banjir di daerah tersebut.

\section{TUJUAN DAN LINGKUP ANALISIS}

\section{TUJUAN ANALISIS}

Tujuan kajian ini antara lain adalah mengevaluasi permasalahan banjir pada sistem drainase dan menyusun rencana sistem drainase (dimensi saluran, dan dimensi bangunan pelengkap) di kawasan Pusat Kota Palopo sehingga diharapkan bisa membantu dalam memecahkan permasalahan banjir di daerah tersebut.

\section{LINGKUP ANALISIS}

Kajian perencanaan sistem drainase mencakup kajian-kajian sebagai berikut: 
1. Pengujian data awal, normalisasi data dan transformasi data curah hujan serta tipe distribusi curah hujan yang paling cocok.

2. Penghitungan curah hujan rencana dengan metode Gumbel, Hasper dan Iwai.

3. Penghitungan nilai intensitas hujan dengan metode Talbot dan Sherman.

4. Penghitungan nilai debit rencana.

5. Penghitungan dimensi rencana saluran drainase dan bangunan pelengkap.

\section{TINJAUAN PUSTAKA}

\section{Definisi Drainase}

Drainase adalah suatu cara pembuang-an kelebihan air yang tidak diinginkan pada suatu daerah, serta cara - cara penanggulangan akibat yang ditimbulkan oleh kelebihan air. Maksud dan tujuan drainase adalah membuang air di atas permukaan tanah yang berlebihan atau menurunkan atau menjaga muka air tanah agar tidak terjadi genangan, sehingga akibat negatif dengan adanya genangan dapat dihindari (Soehardjono, $1984: 3$ ).

\section{Analisis Hidrologi}

Untuk keperluan rencana sistem drainase, data hidrologi yang sangat diperlukan adalah data curah hujan dari stasiun pengamatan hujan daerah kajian. Data ini harus dikumpulkan dengan jangka waktu cukup panjang yang diambil dari beberapa stasiun penakar hujan di daerah kajian studi. Dengan data pengamatan pada masing-masing stasiun penakar hujan tersebut diambil curah hujan rerata masing-masing daerah. Dalam perhitungan curah hujan rancangan maksimum digunakan analisis frekuensi yang sesuai dengan data-data yang diperoleh. Untuk mengetahui kebenar-an dari analisis frekuensi yang digunakan, maka diperlukan uji kecocokan distribusi frekuensi.

\section{Curah Hujan Pengamatan}

Curah hujan dapat diukur menggunakan alat ukur hujan yang umumnya disebut sukat hujan (RainGauge). Satuan untuk mengukur curah hujan adalah $1 \mathrm{~mm}$. Nilai itu menunjukkan bahwa tebal air hujan menutup di atas permukaan bumi setebal 1 
mm, dan zat cair itu tidak meresap ke dalam tanah atau tidak menguap kembali ke atmosfir. Jenis alat pengukur curah hujan dibedakan menjadi dua yaitu:

- alat ukur hujan biasa (AUHB) atau rain gauge (RG)

- alat ukur hujan otomatik (AUHO) atau automatic rain fall recorder (ARR)

\section{Analisa Debit Rencana}

Debit rencana adalah besarnya debit yang direncanakan untuk suatu periode waktu yang direncanakan. Metode rasional banyak digunakan untuk memperkirakan debit puncak yang ditimbulkan oleh hujan keras pada daerah tangkapan (DAS) kecil. Suatu DAS dianggap kecil bila distribusi hujan dapat dianggap seragam dalam ruang dan waktu.

\section{Intensitas Curah Hujan}

Intensitas hujan adalah kedalaman air hujan atau tinggi air hujan per satuan waktu (Suripin, 2004). Sifat umum hujan adalah makin singkat hujan berlangsung, intensitas-nya cenderung makin tinggi dan makin besar periode ulangnya, makin tinggi pula intensitasnya. Jika yang tersedia adalah data curah hujan jangka pendek maka intensitas hujan dapat dihitung dengan rumus Talbot, Sherman dan Ishiguro. Namun apabila data hujan jangka pendek/menitan tidak tersedia, yang ada hanya data hujan harian, maka intensitas hujan dapat dihitung dengan rumus Mononobe (Suripin, 2004).

\section{HASIL DAN PEMBAHASAN}

\section{Analisis Curah Hujan Maksimum Tahunan}

Data hidrologi dalam penelitian ini dipakai data curah hujan dari AWLR PT INCO Tbk, Dalam pengolahan data curah hujan ini diambil dari tinjauan curah hujan harian maksimum (mm) seperti disajikan pada Tabel 1. 
Tabel 1. Data Curah Hujan AWLR PT. INCO.Tbk

\begin{tabular}{|c|c|c|c|}
\hline \multirow{3}{*}{ Hari } & \multicolumn{3}{|c|}{ Curah Hujan (mm) } \\
\hline & \multicolumn{3}{|c|}{ Pembacaan bulan } \\
\hline & Januari & Maret & Мey \\
\hline 1 & 107,07 & 127,22 & 132,48 \\
\hline 2 & 111,32 & 132,67 & 126,59 \\
\hline 3 & 117,99 & 125,93 & 127,43 \\
\hline 4 & 119,64 & 128,19 & 130,12 \\
\hline 5 & 114,55 & 127,21 & 130,98 \\
\hline 6 & 119,43 & 129,94 & 124,90 \\
\hline 7 & 117,81 & 125,32 & 123,32 \\
\hline 8 & 125,07 & 129,45 & 128,27 \\
\hline 9 & 122,13 & 123,12 & 126,69 \\
\hline 10 & 123,00 & 123,34 & 130,23 \\
\hline 11 & 127,21 & 129,23 & 133,54 \\
\hline 12 & 124,51 & 135,54 & 133,89 \\
\hline 13 & 122,49 & 131,43 & 124,76 \\
\hline 14 & 122,97 & 132,53 & 124,22 \\
\hline 15 & 129,48 & 129,32 & 121,51 \\
\hline 16 & 127,24 & 125,76 & 126,88 \\
\hline 17 & 128,75 & 128,56 & 121,23 \\
\hline 18 & 125,95 & 132,21 & 126,67 \\
\hline 19 & 131,11 & 131,97 & 122,56 \\
\hline 20 & 137,49 & 130,21 & 124,80 \\
\hline 21 & 138,48 & 126,77 & 117,32 \\
\hline 22 & 136,79 & 123,83 & 115,64 \\
\hline 23 & 131,85 & 127,12 & 118,27 \\
\hline 24 & 133,53 & 126,32 & 117,43 \\
\hline 25 & 133,53 & 122,92 & 113,22 \\
\hline 26 & 133,69 & 119,85 & 119,11 \\
\hline
\end{tabular}




\begin{tabular}{|l|l|l|l|}
27 & 131,85 & 120,69 & 120,10 \\
\hline 28 & 129,32 & 117,32 & 116,69 \\
\hline 29 & 132,69 & 114,90 & 115,85 \\
\hline 30 & 130,16 & 111,43 & 114,16 \\
\hline 31 & 131,00 & 113,11 & 109,95 \\
\hline
\end{tabular}

\section{Analisis Curah Hujan Rencana}

Perhitungan curah hujan rencana dilakukan dengan menggunakan metode Gumbel, Hasper dan Iwai.

Menentukan Curah Hujan maksimum

\begin{tabular}{|c|c|c|c|c|c|}
\hline \multirow{2}{*}{ No } & \multirow{2}{*}{$\begin{array}{c}\text { Periode } \\
\text { Ulang }\end{array}$} & \multicolumn{4}{|c|}{ Curah Hujan ( mm ) } \\
\cline { 3 - 6 } & & Hasper & Iwai & Gumbel & Maks \\
\hline 1 & 2 & 129,10 & 61,367 & 124,417 & 129,10 \\
\hline 2 & 5 & 131,55 & 67,003 & 130,793 & 131,55 \\
\hline 3 & 10 & 133,31 & 70,094 & 135,015 & 135,01 \\
\hline 4 & 15 & 134,36 & 71,669 & 135,01 & 135,01 \\
\hline
\end{tabular}

\section{Analisis Intensitas Hujan}

Perhitungan Intensitas Hujan dilakukan dengan menggunakan metode Talbot dan Sherman.

\begin{tabular}{|c|c|c|c|c|}
\hline $\begin{array}{c}\text { Durasi } \\
(\mathrm{t})\end{array}$ & \multicolumn{4}{|c|}{$\begin{array}{c}\text { Intensitas Curah Hujan (I) } \\
\mathrm{mm} / \mathrm{jam}\end{array}$} \\
\hline Menit & $\mathrm{I}_{2}$ & $\mathrm{I}_{5}$ & $\mathrm{I}_{10}$ & $\mathrm{I}_{15}$ \\
\hline \hline 5 & 92953,36531 & 94713,02641 & 97210,61957 & 97210,61957 \\
\hline 10 & 46476,68266 & 47356,5132 & 48605,30979 & 48605,30979 \\
\hline
\end{tabular}




\begin{tabular}{|c|c|c|c|c|}
\hline 15 & 30984,4551 & 31571,0088 & 32403,53986 & 32403,53986 \\
\hline 20 & 23238,34133 & 23678,2566 & 24302,65489 & 24302,65489 \\
\hline 25 & 18590,67306 & 18942,60528 & 19442,12391 & 19442,12391 \\
\hline 30 & 15492,22755 & 15785,5044 & 16201,76993 & 16201,76993 \\
\hline 35 & 13279,05219 & 13530,43234 & 13887,23137 & 13887,23137 \\
\hline 40 & 11619,17066 & 11839,1283 & 12151,32745 & 12151,32745 \\
\hline 45 & 10328,1517 & 10523,6696 & 10801,17995 & 10801,17995 \\
\hline 50 & 9295,336531 & 9471,302641 & 9721,061957 & 9721,061957 \\
\hline 55 & 8450,305937 & 8610,275128 & 8837,329052 & 8837,329052 \\
\hline 60 & 7746,113776 & 7892,752201 & 8100,884965 & 8100,884965 \\
\hline 65 & 7150,25887 & 7285,617416 & 7477,739967 & 7477,739967 \\
\hline 70 & 6639,526094 & 6765,216172 & 6943,615684 & 6943,615684 \\
\hline 75 & 6196,891021 & 6314,20176 & 6480,707972 & 6480,707972 \\
\hline 80 & 5809,585332 & 5919,56415 & 6075,663723 & 6075,663723 \\
\hline 85 & 5467,845018 & 5571,354494 & 5718,27174 & 5718,27174 \\
\hline 90 & 5164,075851 & 5261,8348 & 5400,589976 & 5400,589976 \\
\hline
\end{tabular}

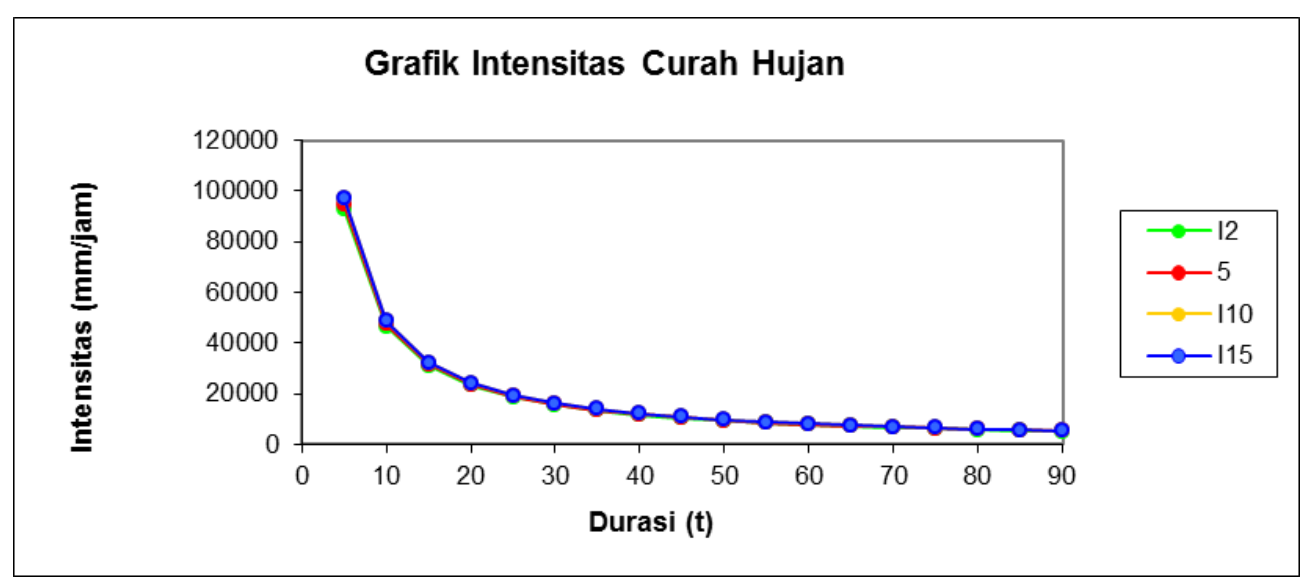


Intensitas Curah Hujan Dengan Metode Talbot

\begin{tabular}{|c|c|c|c|c|}
\hline \multirow{2}{*}{$\frac{\text { Durasi }(\mathrm{t})}{\text { Menit }}$} & \multicolumn{4}{|c|}{$\begin{array}{c}\text { Intensitas Curah Hujan (I) } \\
\text { mm/jam }\end{array}$} \\
\hline & $\mathrm{I}_{2}$ & $\mathrm{I}_{5}$ & $\mathrm{I}_{10}$ & $\mathrm{I}_{15}$ \\
\hline 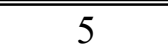 & 88,89796151 & 103,9051582 & 1114,8027896 & 122,2579694 \\
\hline 10 & 44,44898076 & 51,95257909 & 57,40139481 & 61,12898469 \\
\hline 15 & 29,63265384 & 34,63505273 & 38,26759654 & 40,75265646 \\
\hline 20 & 22,22449038 & 25,97628955 & 28,70069741 & 30,56449235 \\
\hline 25 & 17,7795923 & 20,78103164 & 22,96055793 & 24,45159388 \\
\hline 30 & 14,81632692 & 17,31752636 & 19,13379827 & 20,37632823 \\
\hline 35 & 12,69970879 & 14,84359403 & 16,40039852 & 17,4654242 \\
\hline 40 & 11,11224519 & 12,98814477 & 14,3503487 & 15,28224617 \\
\hline 45 & 9,877551279 & 11,54501758 & 12,75586551 & 13,58421882 \\
\hline 50 & 8,889796151 & 10,39051582 & 11,48027896 & 12,22579694 \\
\hline 55 & 8,081632865 & 9,445923472 & 10,43661724 & 11,11436085 \\
\hline 60 & 7,408163459 & 8,658763182 & 9,566899136 & 10,18816412 \\
\hline 65 & 6,838304732 & 7,992704476 & 8,830983817 & 9,404459183 \\
\hline 70 & 6,349854394 & 7,421797013 & 8,200199259 & 8,732712099 \\
\hline 75 & 5,926530767 & 6,927010546 & 7,653519308 & 8,150531292 \\
\hline 80 & 5,556122594 & 6,494072387 & 7,175174352 & 7,641123086 \\
\hline 85 & 5,229291854 & 6,112068129 & 6,753105272 & 7,191645258 \\
\hline 90 & 4,938775639 & 5,772508788 & 6,377932757 & 6,79210941 \\
\hline
\end{tabular}

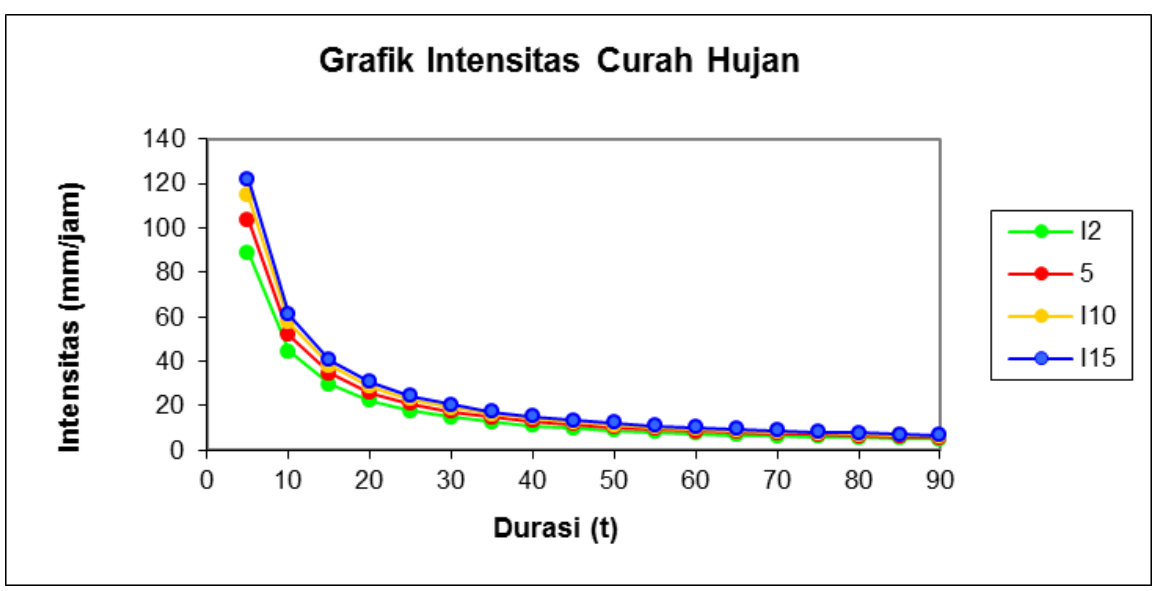




\section{Debit Rencana}

Perhitungan debit rencana dilakukan dengan menggunakan persamaan Rasional.

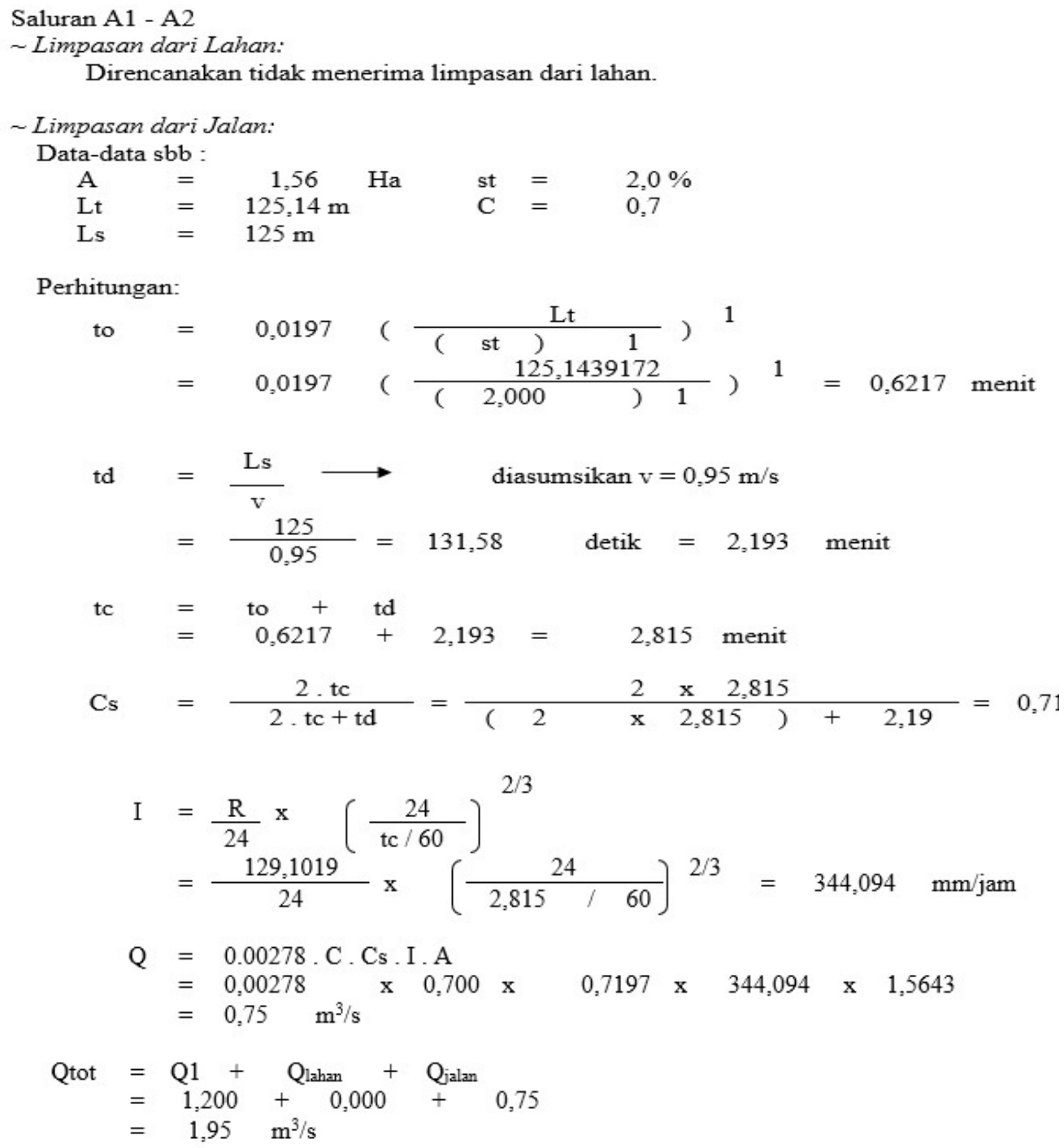


Analisis data sebagai berikut: (mis: Saluran A1 - A2).

Tabel Debit Rencana

\begin{tabular}{|c|c|c|c|c|c|}
\hline No & $\begin{array}{c}\text { Nama } \\
\text { Saluran }\end{array}$ & $\begin{array}{l}\text { Debit } \\
\text { Total } \\
2 \text { thn } \\
\left(\mathrm{m}^{3} / \mathrm{s}\right)\end{array}$ & $\begin{array}{c}\text { Debit Total } \\
5 \text { thn } \\
\left(\mathrm{m}^{3} / \mathrm{s}\right)\end{array}$ & $\begin{array}{c}\text { Debit Total } \\
10 \text { thn } \\
\left(\mathrm{m}^{3} / \mathrm{s}\right)\end{array}$ & $\begin{array}{c}\text { Debit Total } \\
15 \text { thn } \\
\left(\mathrm{m}^{3} / \mathrm{s}\right)\end{array}$ \\
\hline (1) & (2) & (3) & (4) & (5) & (6) \\
\hline 1 & $\mathrm{~A} 1-\mathrm{A} 2$ & 1,95 & 1,97 & 1,99 & 1,99 \\
\hline 2 & $\mathrm{~A} 1-\mathrm{A} 3$ & 2,39 & 2,41 & 2,44 & 2,44 \\
\hline 3 & $\mathrm{~A} 2-\mathrm{A} 4$ & 3,86 & 3,91 & 3,98 & 3,98 \\
\hline 4 & A3 - A4 & 4,01 & 4,06 & 4,13 & 4,13 \\
\hline 5 & B1 - B2 & 1,67 & 1,70 & 1,74 & 1,74 \\
\hline 6 & B1 - B3 & 1,19 & 1,21 & 1,24 & 1,24 \\
\hline 7 & $\mathrm{~B} 2-\mathrm{B} 4$ & 2,85 & 2,91 & 2,99 & 2,99 \\
\hline 8 & $\mathrm{~B} 3-\mathrm{B} 4$ & 11,89 & 12,07 & 12,32 & 12,32 \\
\hline 9 & $\mathrm{C} 1-\mathrm{C} 2$ & 1,42 & 1,45 & 1,49 & 1,49 \\
\hline 10 & $\mathrm{C} 1-\mathrm{C} 3$ & 1,19 & 1,21 & 1,24 & 1,24 \\
\hline 11 & $\mathrm{C} 2-\mathrm{C} 4$ & 3,82 & 3,89 & 3,99 & 3,99 \\
\hline 12 & C3 - C4 & 3,73 & 3,80 & 3,90 & 3,90 \\
\hline 13 & D1 - D2 & 0,38 & 0,39 & 0,40 & 0,40 \\
\hline 14 & D1 - D3 & 1,21 & 1,23 & 1,27 & 1,27 \\
\hline 15 & D2 - D4 & 3,09 & 3,13 & 3,18 & 3,18 \\
\hline 16 & D3 - D4 & 2,32 & 2,36 & 2,42 & 2,42 \\
\hline 17 & E1 - E2 & 2,15 & 2,17 & 2,19 & 2,19 \\
\hline 18 & E1 - E3 & 3,32 & 3,36 & 3,41 & 3,41 \\
\hline 19 & E2 - E4 & 4,89 & 4,96 & 5,05 & 5,05 \\
\hline 20 & E3 - E4 & 5,28 & 5,35 & 5,46 & 5,46 \\
\hline 21 & $\mathrm{~F} 1-\mathrm{F} 2$ & 1,67 & 1,70 & 1,74 & 1,74 \\
\hline 22 & $\mathrm{~F} 1-\mathrm{F} 3$ & 1,67 & 1,70 & 1,74 & 1,74 \\
\hline
\end{tabular}




\begin{tabular}{|c|c|c|c|c|c|}
\cline { 3 - 6 } 23 & $\mathrm{~F} 2-\mathrm{F} 4$ & 3,33 & 3,40 & 3,49 & 3,49 \\
\hline 24 & $\mathrm{~F} 3-\mathrm{F} 4$ & 4,86 & 4,95 & 5,08 & 5,08 \\
\hline 25 & $\mathrm{G} 1-\mathrm{G} 2$ & 1,42 & 1,45 & 1,49 & 1,49 \\
\hline 26 & $\mathrm{G} 1-\mathrm{G} 3$ & 0,75 & 0,77 & 0,79 & 0,79 \\
\hline 27 & $\mathrm{G} 3-\mathrm{G} 4$ & 2,98 & 3,03 & 3,11 & 3,11 \\
\hline 28 & $\mathrm{G} 2-\mathrm{G} 4$ & 10,75 & 10,95 & 11,24 & 11,24 \\
\hline 29 & $\mathrm{H} 1-\mathrm{H} 2$ & 0,13 & 0,13 & 0,14 & 0,14 \\
\hline 30 & $\mathrm{H} 1-\mathrm{H} 3$ & 0,77 & 0,78 & 0,80 & 0,80 \\
\hline 31 & $\mathrm{H} 3-\mathrm{H} 4$ & 1,51 & 1,53 & 1,57 & 1,57 \\
\hline 32 & $\mathrm{H} 2-\mathrm{H} 4$ & 6,90 & 7,01 & 7,17 & 7,17 \\
\hline 33 & $\mathrm{I} 1-\mathrm{I} 2$ & 1,42 & 1,45 & 1,49 & 1,49 \\
\hline 34 & $\mathrm{I} 1-\mathrm{I} 4$ & 1,67 & 1,70 & 1,74 & 1,74 \\
\hline 35 & $\mathrm{I} 2-\mathrm{I} 3$ & 18,06 & 18,40 & 18,89 & 18,89 \\
\hline 36 & $\mathrm{I} 3-\mathrm{I} 4$ & 29,00 & 29,55 & 30,33 & 30,33 \\
\hline 37 & $\mathrm{X} 3-\mathrm{X} 4$ & 11,84 & 11,98 & 12,18 & 12,18 \\
\hline 38 & $\mathrm{X} 4-\mathrm{X} 5$ & 8,19 & 8,35 & 8,57 & 8,57 \\
\hline 39 & $\mathrm{X} 6-\mathrm{X} 7$ & 8,40 & 8,54 & 8,74 & 8,74 \\
\hline 40 & $\mathrm{X} 7-\mathrm{X} 8$ & 39,07 & 39,79 & 40,82 & 40,82 \\
\hline
\end{tabular}


DYNAMIC SAINT

JDS, Jilid III no. 2, April 2018

Perencanaan Dimensi Saluran

Rumus yang digunakan :

$$
\begin{aligned}
& \mathrm{A}=\frac{\text { Q maks }}{\text { Vrencana }} \\
& \text { asumsi } \frac{\mathrm{b}}{\mathrm{h}}=1,5 \\
& \mathrm{~A}=(\mathrm{b}+(\mathrm{mxh})) \times \mathrm{h} \\
& A=(1.5 \mathrm{~h}+(0,5 \times \mathrm{x})) \mathrm{xh} \\
& \mathrm{A}=2 \mathrm{~h}^{2} \\
& \mathrm{P} \quad=\quad \mathrm{b}+2 \mathrm{~h}(\mathrm{~m}+1)^{0,5} \\
& \mathrm{w} \quad=0,25 \mathrm{~h}+ \\
& \mathrm{R}=\frac{\mathrm{A}}{\mathrm{P}} \\
& S=\left(\frac{V x n}{R^{2 / 3}}\right)^{2}
\end{aligned}
$$

Contoh Perhitungan Saluran A1 - A2

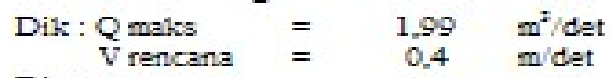

Dit :

h...??
peny:

$A=\frac{\text { Qenaks }}{\text { Vrencana }}=\frac{1.98833}{0.4}=4.97084 \mathrm{~m}^{2}$

$A=(b+(m x h)) \times h$

$A=(1.5 \mathrm{~h}+(0.5 \times \mathrm{h})) \times \mathrm{h}$

A.

$\mathrm{h}=\sqrt{\frac{\mathrm{A}}{2}}=\sqrt{\frac{4,97084}{2}}=1,57652 \mathrm{~m}$

$\mathrm{b}=1.5 \mathrm{x} 1.57652=2,36478 \mathrm{~m}$

P $=b+2 h(m+1)^{0, s}$

$=2.36478+3.15304 \times 1,22474$

$=6.22645 \mathrm{~m}$

$\begin{aligned} & =0,25 \mathrm{~h}+0,3 \\ & =0,69413 \mathrm{~m}\end{aligned}$

$\mathrm{R}=\frac{\mathrm{A}}{\mathrm{P}}=\frac{4,97084}{6,22645}=0,79834 \mathrm{~m}$

$s=\left(\begin{array}{ccc}0,4 & x & 0,025 \\ 0,798341633 & 0,57\end{array}\right]^{2}=0,000135025=0,014 \%$ 
DYNAMIC SAINT

JDS, Jilid III no. 2, April 2018

SKETSA SALURAN A1 - A2

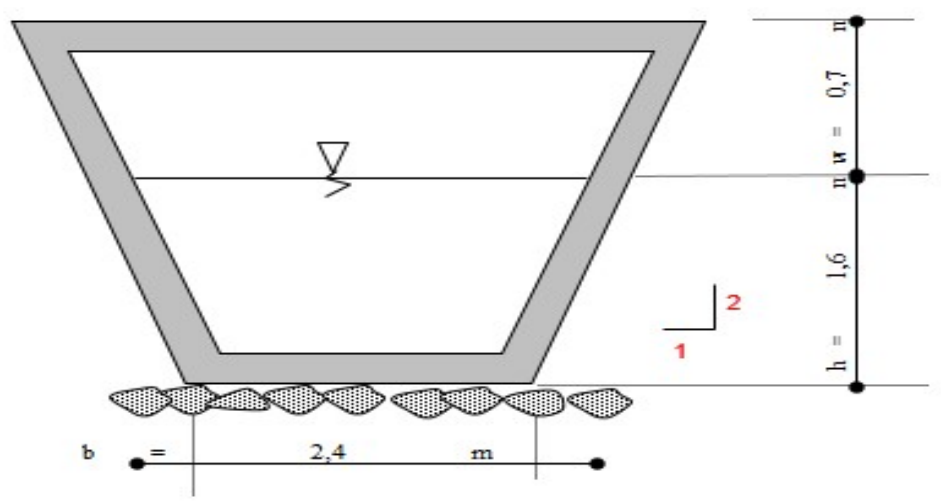

Perencanaan Gorong - Gorong

Rumus yang digunakan :

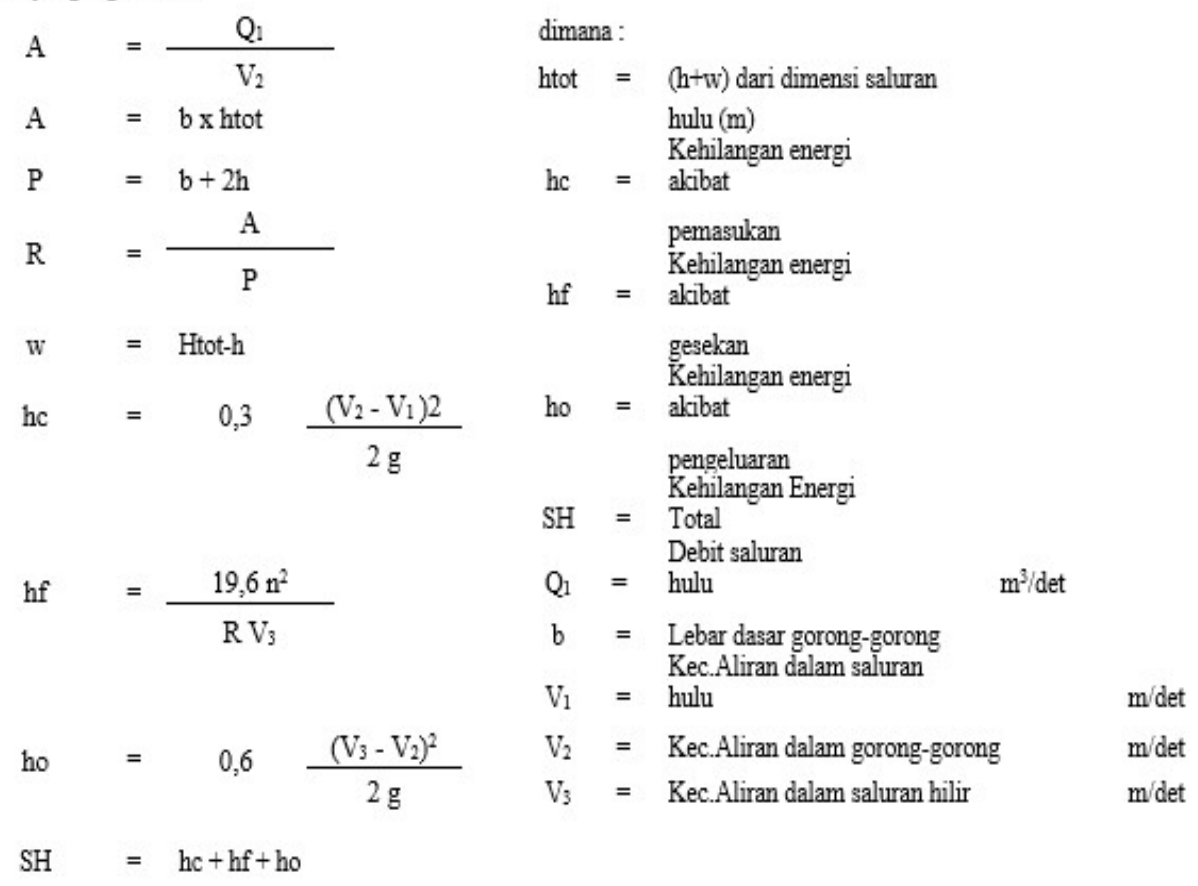




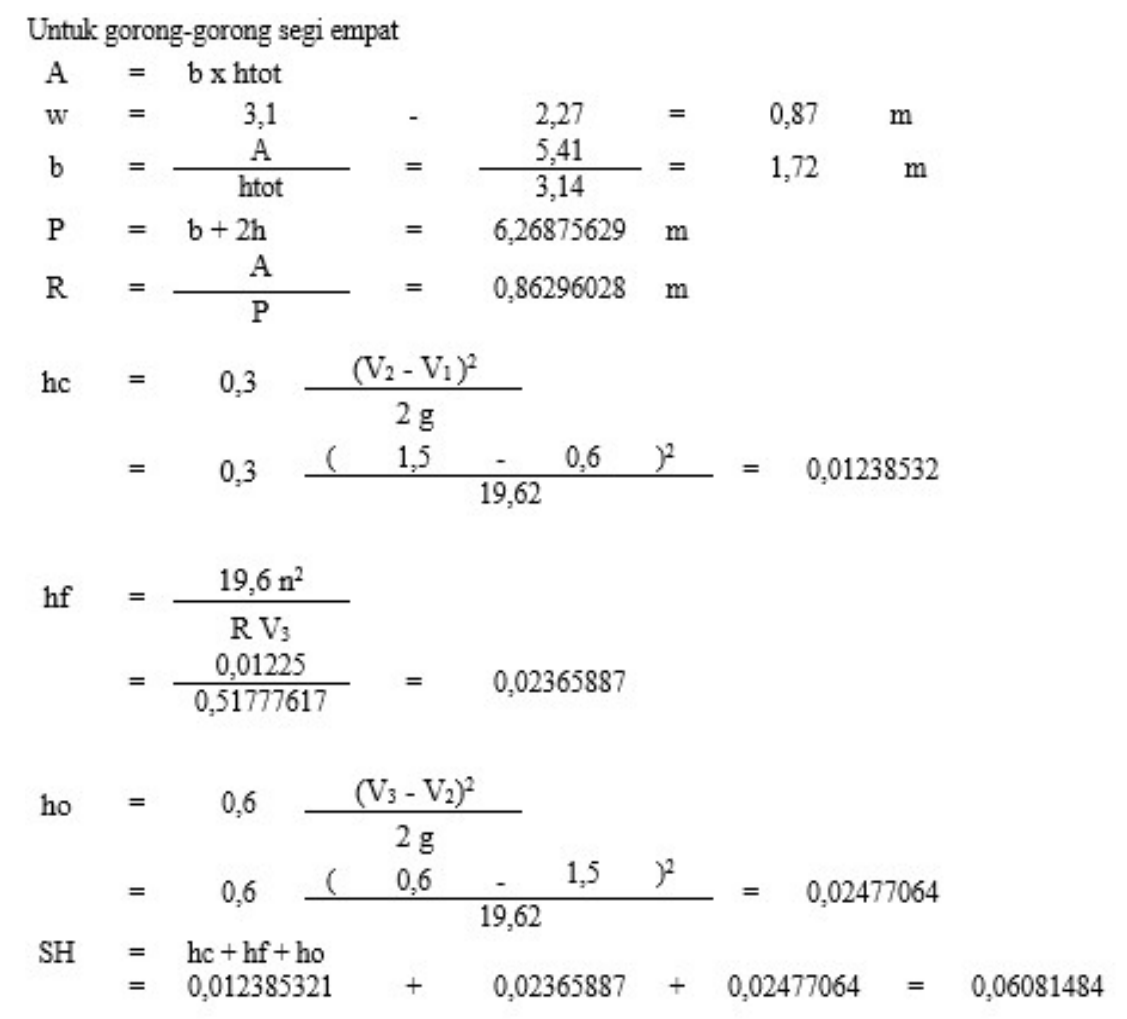

SKETSA GORONG-GORONG A4 - B3

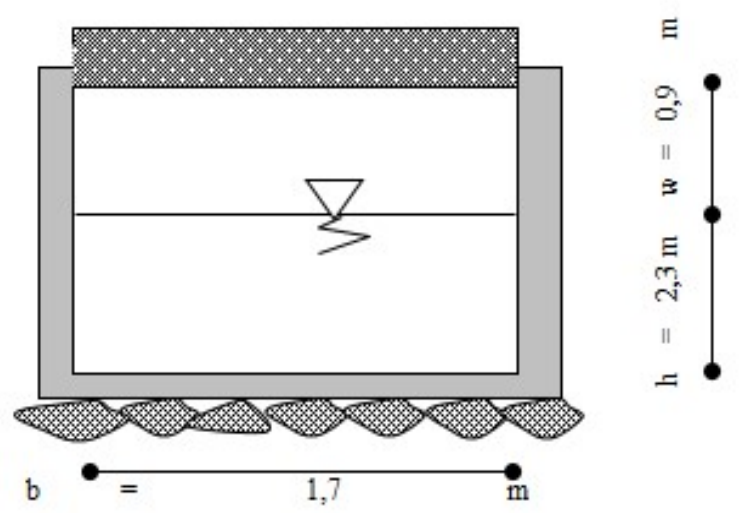




\section{KESIMPULAN DAN SARAN}

\section{KESIMPULAN}

Berdasarkan pembahasan dan analisis, maka dapat disimpulkan sebagai berikut:

1. Untuk mengantisipasi masalah genangan air hujan dibuat sistem jaringan saluran yang baru.

2. Setelah dilakukan perencanaan ulang dimensi saluran, diperoleh dimensi saluran yang bisa menampung debit aliran air di daerah tersebut.

3. Dari hasil perencanaan sistem drainase, diperoleh hasil untuk dimensi drainase yakni $\mathrm{b}=2,4 \mathrm{~m}$ dan $\mathrm{h}=1,6 \mathrm{~m} \mathrm{~W}=0,7 \mathrm{~m}$ dan $\mathrm{Q}=1,95 \mathrm{~m}^{3} / \mathrm{det}$, dengan bentuk saluran trapesium. Untuk banguna gorong - gorong diperoleh hasil untuk dimensi gorong - gorong yakni $\mathrm{b}=1,7 \mathrm{~m}$ danh $=2,3 \mathrm{~m} \mathrm{~W}=0,9$ $\mathrm{m}$ dan $\mathrm{Q}=8,1 \mathrm{~m}^{3} /$ det, dengan bentuk gorong - gorong segiempat.

\section{SARAN}

1. Diperlukan kajian yang mendalam terkait masalah perencanaan drainase perkotaan dan Perlu adanya Data pendukung sebagai input untuk hal-hal terkait masalah ketelitian, kevalidan, serta akurasi dari output.

2. Ruang lingkup saluran drainase yang direncanakan dapat diperluas hingga ke saluran yang lebih kecil yaitu saluran tersier. 


\section{DAFTAR PUSTAKA}

Anonim. 1986. Kriteria Perencanaan Bagian Saluran KP-03. Departemen PU, Jakarta.

Anonim. 1997. Drainase Perkotaan. Gunadharma, Jakarta.

Dewan Standarisasi Nasional. 1994. Tata Cara Perencanaan Drainase Permukaan Jalan (SNI 03-3424-1994). YBPPU, Jakarta.

Direktorat Jenderal Pengairan. 1980. Pedoman dan Kriteria Perencanaan Teknis Irigasi. Depatemen PU, Jakarta.

Soemarto, C.D. 1987. Hidrologi Teknik. Usaha Nasional. Surabaya-Indonesia.

Sunandar, A., Soedjono, E.S., BS, Didik. 2005. Optimalisasi Sistem Pengelolaan Drainase Kota Bandung (studi kasus: Kecamatan Arcamanik). Suripin. 2004. Sistem Drainase Perkotaan yang Berkelanjutan. Andi. Yogyakarta. Standar Perencanaan Irigasi. 1986. KP04 Bagian Bangunan. Direktorat Sumber Daya Air. Jakarta.

Tanudjaja, L. 2009. Materi Kuliah Drainase Dan Pengendalian Banjir. Program Studi S-1 Teknik Sipil Fakultas Teknik Universitas Sam Ratulangi. Manado. 